\title{
Methodological analysis of speaking activities in secondary school textbooks
}

\section{Nigora BAKHODIROVA ${ }^{1}$}

Namangan State University

\begin{tabular}{l} 
ARTICLE INFO \\
\hline Article history: \\
Received January 2021 \\
Received in revised form \\
15 January 2021 \\
Accepted 20 February 2021 \\
Available online \\
7 March 2021 \\
\\
\hline Keywords: \\
Technique \\
Speaking activities \\
Drilling \\
Information gap activities \\
Discussion
\end{tabular}

ABSTRACT

Today, in a competitive world knowing foreign languages is becoming more and more important. Due to lack of communication skills, learners of today are facing numerous problems in expressing their thoughts and ideas properly in English even if they know and express the same in their mother tongue. Now the responsibility mainly is on the shoulders of the English language teachers to train the EFL/ESL learners properly and systematically in applying these skills for their bright career by adopting innovative and novel techniques and strategies in the classroom. This article aims to analyze various types of activities and techniques in textbooks at secondary schools.

2181-1415/C) 2021 in Science LLC.

This is an open access article under the Attribution 4.0 International (CC BY 4.0) license (https://creativecommons.org/licenses/by/4.0/deed.ru)

\section{Umumiy o'rta ta'lim maktabi darsliklarida nutqga oid mashqlarning metodologik tahlili}

\author{
Калит суцзлар: \\ Texnika \\ Nutq faoliyati \\ Burg'ulash \\ Axborot bo'shliqlari faoliyati \\ Munozara
}

\begin{abstract}
АННОТАЦИЯ
Bugungi kunda raqobatdosh dunyoda chet tillarini bilish tobora muhim ahamiyat kasb etmoqda. Kommunikativ qobiliyatining yetishmasligi sababli, bugungi kunda o'quvchilar o'zlarining fikrlarini va g'oyalarini o'z ona tillarida bilsalar ham va ifoda etsalar ham ingliz tilida to'g'ri ifoda etishda ko'plab muammolarga duch kelmoqdalar. Endilikda mas'uliyat asosan ingliz tili o'qituvchilarining zimmasiga sinfda innovatsion va yangi uslublar va strategiyalarni qo'llash orqali o'quvchilariga ushbu ko'nikmalarni amaliyotda qo'llashda to'g'ri va tizimli ravishda o'rgatishdir. Ushbu maqola umumta'lim maktablaridagi darsliklardagi turli xil nutq faoliyati turlari va usullarini tahlil qilishga qaratilgan.
\end{abstract}

\footnotetext{
${ }^{1}$ Master's student, Namangan State University, Namangan, Uzbekistan

E-mail: baxodirovanigora@gmail.com
} 


\section{Методологический анализ голосовой деятельности в средней школе учебники}

\begin{tabular}{l}
\hline Ключевые слова: \\
Техника \\
Разговорная деятельность \\
Бурение \\
Информационные \\
пробелы \\
Дискуссия
\end{tabular}

\section{АННОТАЦИЯ}

Сегодня в конкурентном мире знание иностранных языков становится все более важным. Из-за отсутствия коммуникативных навыков современные учащиеся сталкиваются с многочисленными проблемами при правильном выражении своих мыслей и идей на английском языке, даже если они знают и выражают то же самое на своем родном языке. Теперь на плечах учителей английского языка лежит ответственность за правильное и систематическое обучение учащихся EFL / ESL применению этих навыков для их успешной карьеры путем внедрения инновационных и новаторских методов и стратегий в классе. В данной статье анализируются различные виды деятельности и приемы в учебниках средней школы..

Language learning is a constant process that begins at birth and continues till the end of life. Language learning is an important part of life through which people are able to communicate and share thoughts, opinions, information, experiences and feelings and learn to understand themselves and understand others. They even establish their relationships with the members of their family, friends and others. According to Oxford English Dictionary, "Speaking is the action of conveying information or expressing one's feelings in speech". We need to communicate well with others in order to fulfill our goals or life ambitions.

The English language teachers need to implement various innovative activities in the classroom in the process of teaching speaking skills. These activities enhance the speaking skills of learners and help them in their personal as well as professional development. Let us discuss these activities in a detailed way for a clear understanding for the English teachers to implement them successfully in order to achieve communicative competence among the learners. It is almost impossible to teach speaking separately. To reach our goals we need at least to integrate listening skill and sub skills like grammar and vocabulary with speaking. In Uzbekistan English textbooks are being created focusing on learner-centered methodology and Communicative language teaching is the main character of course books.

According to Brown's (2001) classification of six distinctive categories of classroom speaking performances as the framework of analysis, the following explanation elaborates on each kind of them.

\section{IMITATIVE}

It focuses of this category is pure in phonetic level of oral production. It has nothing to do with pupil's comprehension (Brown 2004). The only role of them is to repeat what they listen from a human tape recorder, like practice an intonation contour or pronounce a certain vowel sound correctly. The activity is called drilling. Brown (2003) stated about drills as follows: Drills offer students an opportunity to listen and to orally repeat certain strings of language that may pose some linguistics difficulty- either phonological or 
grammatical. Drills are commonly used in Audio-Lingual Method. The goal of this method is to use the target language communicatively. Larsen-Freeman (2000) states that the goal of teachers who use the Audio-Lingual method is they want their students to be able to use the target language communicatively. 271At schools drilling is really helpful to emphasize a new rule or some difficult part. Chain drill itself gets its name from the chain of conversation that forms around the room as students, one-by-one, ask and answer questions of each other (Larsen-Freeman, 2000). This kind of activities is widely used especially while teaching young learners. Because, they learn more by memorizing. Drilling is one of the best ways to memorize. Drilling and Chain drill activities are widely used in the classrooms of secondary schools.

\section{INTENSIVE}

This category leads the students to produce the language by themselves. The language production is in the form of responding to teachers' question or interacting with others at minimal length of utterance. This technique focuses on a small range of grammatical, phrasal, lexical, or phonological competences. Here, the teacher controls the answers so the answers are fixed. This technique is realized in in activities like Directed Response, Read-Aloud, Sentence/Dialogue Completion, Oral Questionnaire, Picture-Cued, and Translation (of limited stretches of discourse) ect.

\section{RESPONSIVE}

This technique means learners respond to teacher or other learners' questions. The respond is usually short, meaningful, and authentic. Here, pupil's comprehension is taken into account. The activities are: Question and Answer, Giving instruction/direction, Paraphrasing.

Question and Answer is one of the most encountered activities in English textbooks. This kind of activity can be used in greeting the pupils reviewing previous lessons, telling stories, discussing group results, attracting their attention.

\section{INTERACTIVE:}

Transactional (dialogue): The purpose of this technique is to make pupils to enable to covey and exchange facts, information and opinions with others. Interview, Discussion and Games are the activities of this technique.

Another spoken interaction activity that takes place in the English language classroom is 'Information Gap Activities'. Harmer (2002) says, "Where two speakers have different parts of information making up a whole, because they have different information, there is a gap between them". Gap activities are the most useful activities to promote a foreign language or second language acquisition. According to Hedge (2000), These provide negotiation of meaning and the conversational adjustment which push students to more accurate output". He further says, "These involve each learner in pair or group processing information which the other learners do not have. These activities have requirements for information exchange". Information gap activities are useful for various reasons. They provide an opportunity for speaking practice and real communication. The English language teachers can motivate the learners to acquire different skills such as clarifying meaning and rephrasing. 271 
In the English classrooms also, the language teachers have to train the learners to face the interview with positive attitude and self-confidence. Interviews can maximize the amount of communicative and interactional practice between pupils.

'Discussions' or 'Group Discussions' are one among the best ways of speech presentation and it is considered as an interesting form of oral practice in the English classroom. According to the Cambridge English Dictionary, the definition of 'discussion' is, "The activity in which people talk about something and tell each other their ideas or opinions". In textbooks, especially in high grades they are common.

\section{Interactive: Interpersonal (dialogue)}

The purpose of this technique is for maintaining social relationships. The examples of specific activities are Conversation and Role Plays.

Role plays are used to refer to all sorts of activities where learners imagine themselves in a situation outside the classroom, sometimes playing the role of someone other than themselves, and using the language appropriate to this new context. Through role play activities, learners develop their problem-solving and decision-making skills that lead them to gain more experience in cooperative learning and independent learning.

\section{Extensive (monologue)}

In this technique, language production is planned. The activities: Oral presentation, Picture cued storytelling, Retelling a story, News event ect.

King (2002) states, "Oral presentations have been shown to help bridge the gap between language study and language use; that presentations require students to use all four language skills in a naturally integrated way; and that presentations have been shown to encourage students to become active and autonomous learners". Presentations are used even in teaching speaking to young learners as it makes a learner to produce even a sentence confidently.

It can be concluded that using different teaching techniques and activities is a key for a successful result. In order to teach speaking skills effectively, the teachers should go through the recent trends in the English language teaching and undergo training to acquire the latest techniques and approaches and introduce various activities in their classrooms in order to make the learners more proficient and skillful in their speaking skills.

\section{References:}

1. Brown, H.D. (2001). Teaching by Principles: An Interactive Approach to Language Pedagogy. Singapore: Longman.

2. Brown, H. Douglas. (2003). Language Assessment Principles and Classroom Practices. New York: Longman.272p 272

3. Brown, H.D. (2004) Language Assessment: Principles and Classroom Practices. New York: Pearson Longman.

4.Harmer, J. (2002). The Practice of English Language Teaching. Harlow: Longman Press. P.88

5. Hedge, T (2000). Teaching and learning in the language Classroom. Oxford University Press, USA. P. 281

6. King, J. (2002). Preparing EFL learners for oral presentations. Dong Hwa Journal of Humanistic Studies, 4, 401-418272 
7. Larsen-Freeman, Diane. (2000) Techniques and Principles in Language Teaching// New York: Oxford University Press. p.45

8. Oxford English Dictionary Online Edition (2ndEd.) Oxford University Press https://en.oxforddictionaries.com/definition/speaking273

9. Sarimsakova, D. (2020, December). THE MODELS OF COMMUNICATIVE COMPETENCE: DEVELOPING SOCIOLINGUISTIC COMPETENCE IN EFL TEACHING. In Конференции.

10.Muhamadjonovna, S. D. (2020). A Set Of Methodological Tools For The Formation Of Sociolinguistic Competence Of Future English Teachers. The American Journal of Social Science and Education Innovations, 2(12), 298-302.

11.Sarimsakova, D. (2017). Station Rotation. English Teaching Professional, 109. 